\title{
【消費者市民活動部会 部会報告】
}

\author{
廃棄物二法後の自治体清掃行政 \\ —自治体アンケートより——
}

川島 霞 子*・寺 田 加子*

はじめに

廃棄物処理について, 直接の責任者である自治体が法 の改正と新しい資源化促進法をうけてどのような動きを しているのかということは関心のあるところで, '90 年 に「市民・消費者団体の活動」を'91 年「企業の環境, 廃棄物についての取組み」を調查, 今回は 3 回目である。 全国 450 自治体に対し，新たな取組みの現状と問題点， 国に対する意見や要望を聞いた。調査が $6 \sim 7$ 月で，ま だこれからの所む多かったが，「ごみ問題」は各地で差 し迫った問題だけに, 地域差はあっても様々な取組みが 行われている。

廃棄物の量がふえ，質も変ったというが，どの位ふえ たのか, 昭和 60 年に比べての比率を出し, 質の面む聞 いた。中には減少した所ああり，理由も問うてみた。

収集したごみの処理処分は焼却が多いのか埋立か, 資 源化はどの位か, また, かかえている問題は何か, 現状 にてらし，今回の 2 法にはどう対処されるのか，予定は, また, 分別の変更, 排出手数料はどうなのか, 何を有料 としているかなどあ聞いている。

次に「特別管理一般廃栽物」と「特別管理産業廃棄 物」「廃衰物処理困難物」に指定を望む物は何かも聞い た。

廃棄物減量推進審議会および廃棄物減量推進員の設置 あ検討中が多く、リサイクルセンターは設置している所 と計画中が同じ位あり，予定なしがこれを上回っていた。

最後にフリーアンサーで, 国, 事業者, 市民に対する 要望を聞いたが、これにも沢山の意見がよせられている。 調査項目を追って記述する。

原稿受付 1993.4.26

* 消費者市民活動部会

連絡先： 7167 東京都杉並区上井草 3-16-27-211 寺田加子
調查期間 1992 年 6 月 25 日〜 7 月 17 日

調查地域 全国の地方自治体（市）

調查対象 地方自治体清掃事業担当課等

調查方法 郵送による配付回収

配付回収 配付 450 回収 320 (この内, 完全回答の ないものと組合を除いた）有効票 271 回 収率 71\%（実質 60.2\%）（表 1）

（表 1）地方別回収数

\begin{tabular}{|c|c|c|c|c|c|c|c|c|c|c|}
\hline 地方 & 北海道 & 東北 & 関東 & 東京 & 中部 & 近霟 & 中国 & 四国 & 九州 & 合計 \\
\hline 数 & 17 & 31 & 67 & 16 & 34 & 54 & 18 & 10 & 24 & 271 \\
\hline
\end{tabular}

\section{1 廃棄物の増減と処理処分}

昭和 60 年を元に最む新しい数ということで, 排出量 を聞いてみた。それにより増減率を比較してみた（表 2） $90.9 \%$ は増加だが， 50\%以上ふえている所は少な い。20 30\% 位の增加が多い。減少も10\% 台が多く, 記入された数字はなかったが, 減少している所が $5 \%$ 位はあった。

増加したのは「事業系一般廃车物」では図 1 のように, オフィス紙ごみ, 建設廃材が多く, 家庭系一般廃棄物で 特に增加したものは（図2）食品トレーが最も多く, 次 いでペットボトル, 紙, 家電, 缶。成程と思える順位で ある。

その他に事業系では，プラスチック系，包装材料，刈 込の植木, 外食店の旡介。家庭系では, プラスチック類, 単車, 自転車などが上げられている。これら増加した物 の中にもリサイクルできるものが沢山ある。

事業系では紙, 家庭からの紙, トレー, ペットボトル 等, 回収をはじめたスーパーもあるが, リサイクルシス テムを確立し，リサイクルすべきで，廃掃法第三条「事 業者の責務」に明記されている。「事業者はその事業活 
（表 2）収集廃栽物の増減率（対比昭和60年）

\begin{tabular}{|c|c|c|c|c|c|c|c|c|c|c|c|c|c|c|}
\hline & \multicolumn{4}{|c|}{ 增 } & \multicolumn{3}{|c|}{ 加 } & \multicolumn{4}{|c|}{ 率 } & \multicolumn{3}{|c|}{ 減 少 } \\
\hline & 総数 & 19 烸下 & $20 \%$ & $30 \%$ & $40 \%$ & $50 \%$ & $60 \%$ & $70 \%$ & $80 \%$ & $90 \%$ & $100 \%$ & $20 \%$ & $30 \%$ & $\begin{array}{l}\text { 記入 } \\
\text { なし }\end{array}$ \\
\hline 北海道 & 17 & 8 & 3 & & 1 & 1 & & & & & 1 & 1 & 1 & 1 \\
\hline 東 北 & 31 & 2 & 9 & 8 & 1 & 1 & 1 & 1 & 1 & & & 1 & & 6 \\
\hline 関 東 & 67 & 5 & 14 & 17 & 18 & 6 & 2 & 2 & & & & 2 & & 1 \\
\hline 東 京 & 16 & & 2 & 4 & 7 & 1 & & & & & & & & 2 \\
\hline 中 部 & 34 & 10 & 3 & 10 & 6 & & 2 & & & 1 & & 1 & & 1 \\
\hline 近 畿 & 54 & 12 & 16 & 16 & 1 & 5 & & & & & & 2 & & 2 \\
\hline 中 国 & 18 & 8 & 2 & 1 & 3 & & & & 1 & & & 3 & & \\
\hline 四 国 & 10 & 3 & 3 & 1 & 2 & & & & & & & 1 & & \\
\hline 九 州 & 24 & 6 & 7 & 4 & 1 & 2 & 2 & 1 & & & & & & 1 \\
\hline 合 計 & 271 & 54 & 59 & 61 & 40 & 16 & 7 & 4 & 2 & 1 & 1 & 11 & 1 & 14 \\
\hline$N=271$ & $100 \%$ & 19.9 & 21.8 & 22.5 & 14.8 & 5.9 & 2.6 & 1.5 & 0.7 & 0.4 & 0.4 & 4 & 0.4 & 5.1 \\
\hline
\end{tabular}

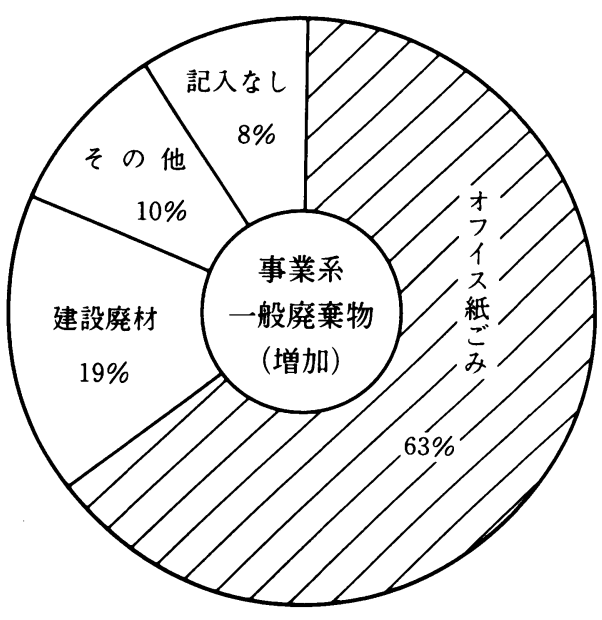

（図1） 事業費系一般廃棄物の増加

動に伴って生じた廃棄物を自らの責任において適正に処 理しなければならない」ごみ減量にはリサイクルが必要 である。

一方減った所の理由を再調査してみた。

(1) 事業系ごみ受入れの見直し

(2) 市民の自助努力による資源化

(3) 回収奖励金制度の実施

(4) 人口の減少

(5) 有料化

ということで，収集されたごみの処理を，焼却，埋立， 資源化，再使用，その他にわけて\%を記入してもらった (図 3 )。総合して, 大半は焼却後理立の所が多く, 資源 化を行政段階で行っている所は少ない。これが本格化さ

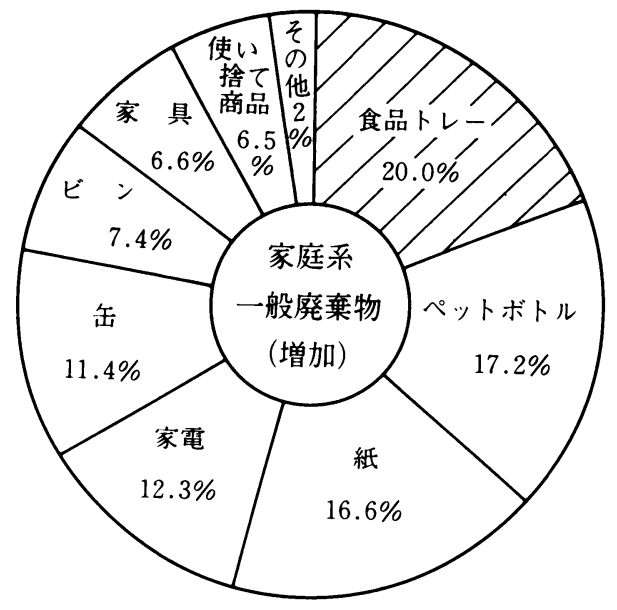

（図 2 ）家庭系一般廃衰物の増加

れれば，かなり減量になる。前問での収集量减少の理由 と考え合せると, 事業系ごみの受入れの見直しも受入れ 制限だけではごみ減量にはならないし，人口減もどこか で人口増になっているので，実質的に減量にならない。 資源化, 有料化之, 市民の自助努力が実質的に減量化に なる。

不用になったものがどのような流れに乗るかが，これ からの減量に大きく影響を与える。責任は製造者, 流通 業者にあり，これを使った消費者もその一端を担っては いる。システムを作るのは行政の責任。資源化はまだま だこれからという感が強い。

では問題点はどうなのだろう, 焼却, 埋立, リサイク ル等についてまとめてみよう。まず焼却場は「問題な 
焼却, 埋立, 資源化の地域別割合

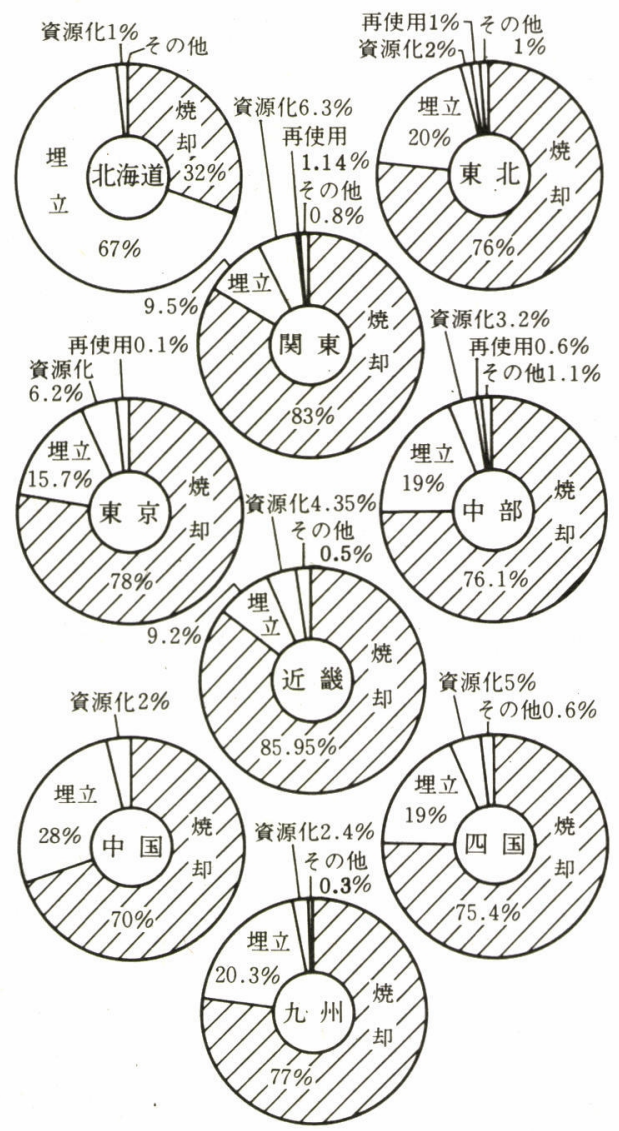

（図 3 ）焼却，埋立，資減化の地域別割合

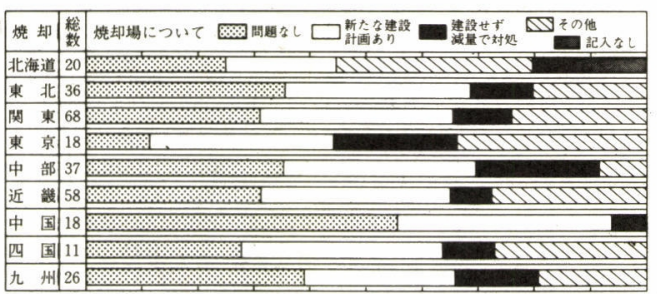

（図 4）焼却場現状と今後

し」とする所が限界に達していて建設計画ありとする所 とと屯に $33 \%$ づつ，建設せず隇量で対処が $11 \%$ ，その 他 $21 \%$ である。これらの問題点は地方によって差があ るのかどうか，調べてみた（図 4 )。その他の項への記 入屯多く, 将来的に可燃物全量焼却・炉の増設も必要之 いう所もありまた資源化工場建設というのあある。老朽 化している所, 現在焼却炉のない所, 建設中の所などの 答があった。またリサイクルセンター建設予定という所 あある。ごみの処理処分は，焼却，埋立が中心である。 次に埋立であるが，東京では「問題なし」という所が
ない。新しい埋立地を探しているが困難，というのが, 東京と中国，四国地方に多い。また，減量により延命を はかるという所は各地方とも多い。

それではその埋立地が満杯になるのはいつなのか。 $「 1$ 年末満」 $2.95 \%, 「 1 \sim 3$ 年」が $13.65 \%, 「 3 \sim 5$ 年」 $16.6 \%, 「 5$ 年以上」が $11.8 \%$,「問題なし」 $18 \%$, 予測がつかないのか記入なしが $36.9 \%$ ああった。しか し処分場がなく，延命をはかるという悲愴な所もある。 ごみ処理は焼却，埋立より方法はないのだろうか。ま ずは必要以上の屯のを買込み十分使用しないで捨てない。 自分の所では不用であ他で使えるのではと行われるのが, ガレージセール，フリーマーケット等いろいろな名称は あるが，市民の生活の知恵である。これに行政が加わっ て区や市に常設の場が設けられている。また回収された 自転車あ高齢者事業団などの協力でリサイクルされてい る。それにしても一度限りの使い捨ての包装容器とか使 い捨て商品は見直されるべきであり值くづれを恐れて未 使用商品まで捨てるに至っては論外である。このような 無駄をはぶき，ごみ予備軍を作らないことである。

次に一度使ったあのあ洗ったりして再使用できるあの をできるだけ使うようにし，資源は捨てずに何度であリ サイクルをする。そうできるものだけが製造されるよう 製品アセスメントあしっかり行われるべきである。

\section{2 リサイクルの現状}

自治体自体がリサイクルを行っているのが $40.5 \%$ ，行 政がシステムをつくり，業者が回収というのが $15 \%$, 住民団体が実施しているのを支援，助成が $44.5 \%$ とか なり行政自体む行っている。支援助成というのも同じ位 の率で行われている。今までは回収した物が, 物として の洒值で売られていたが, 值段が下がってきた現在この 助成でからうじて回収意欲をささえている。

自治体ではどんな物を回収しているのかを聞いてみた。 かなりいろいろなあのが集められている（図5）。その 他としては, 破砕処理後, 磁性物回収が最む多い。また, 粗大ごみ中から再使用可能物を無償提供, 生ごみ処理, 廃食用油回収などがあった。

自治体がシステムづくりをして業者が回収していると ころでは，回収業者助成 $47 \%$ ，場所提供 $18 \% ， そ の$ 他 $35 \%$, その他は, まちづくり推進委員会に委託, 市民行 政回収業者協調方式, モデル地区による回収, 住民の集 団回収の助成屯多い。用具貸出し，コンポスト斡旋助成, などいろいろな形で助成されている。

回収品の量が多くなり，逆有償という中でも回収が続 けられるのはこの助成があるからという所もあるがそう 


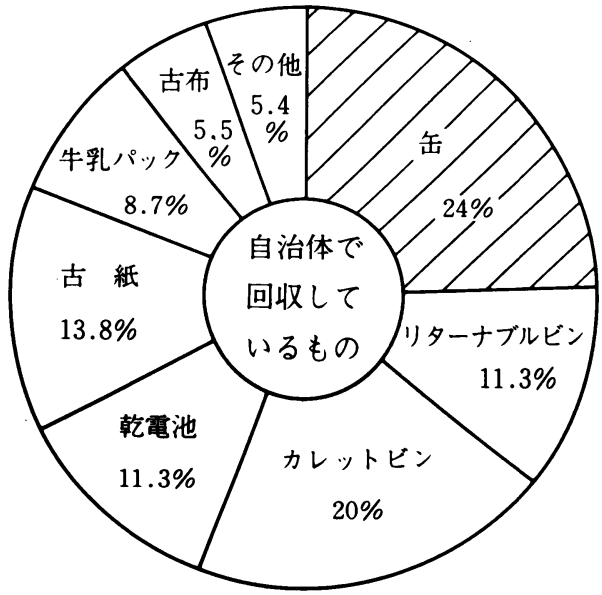

（因5）自治体で回収しているもの

いう事態がおこっていいとはいえない。何とかしてそう いう事態を避けることの方が大切である。

資源がごみとなるのでなく, 活用し, 何度であ再使用, 再利用されるためには，今までの単なる経済性にまかせ るのではなく，そのためのシステムを作る必要があり， これは国の仕事だろう。メーカーが原料として使用する よう，国とともに地方自治体の行政指導あ望みたい。

\section{3 再生資源の利用の促進に関する法律}

略称リサイクル法というこの法律について評価する点, 問題点などを上げてもらった。

（1）製造・販売者責任がうたわれたことは評価。リサ イクル法制定は資源化への取組みとして画期的。

（2）製造者責任が極めて暧昧で現在のままではあまり 役にたたないのではないか。

○本法を再資源の利用促進ガイドラインと受け止 めているが，対象業種の少なさ，リサイクルさ れた原材料の需要の問題などがあり，実効のあ るあのかどうか疑問が残る。

○使い搭て資源消費社会を変革し, リサイクル社 会を構筑するためにそれぞれの責務をむっと明 確に。

○ガイドライン的な事柄が中心。今後は(1)再資源 化への税資金の確保，助成措置の強化，(2)国・ 地方自治体に対し再生品の優先的使用を義務つ ける等の具体化が必要。

(3) 一歩前進だが努力目標的，誰がどうするのか暧昧。

(4) 事業者に対する強制対象品目の指定基準が明確で ない。

（5）法の主旨を具体化するためには，回収システムの
開発整備が必要だ。

。問題なのは，国でのリサイクル・ルートの確立 と企業による引取り義務だ。

（6）企業の再利用の義務づけにより，リサイクルの流 れが拡大安定することを望む。

○リサイクル率を定める業種に製鉄業と，自動車 解体業を指定すべきである。

（7）製造者の責任において，リサイクル処理させる明 確な法体系の整備を望む。

（8）産廃の発生量が増加し，利用されないことがない よう排出者責任を明確にした法体系の整備を望む。 ○特別管理産業廃棄物のみでなく, 建設廃材むマ ニフェストシステムの適用を。

（9）デポジット制度の導入など事業者責任を明確にし た制度に発展させるべきだ。

(10) 経済動向により再生品の利用が左右されないシス テムの確立を望む。

(11) 廃棄物処理事業を行っている市町村の意見反映の 場がない。

(12) 昭和 56 年度より資源回収実施，62 年度に全市へ 拡大，法律は今更の感あり，もっと早期に法制化 してほしかった。

（13）使い捨て商品が増加，製造者段階で許可制を入れ またリターナブル容器使用を国は指導すべきだ。

(14）再資源業界の構造的体質の強化が必要だ。

(15) 「特定業種の指定」と「第 1 種指定製品，第 2 種 指定製品，指定副産物の指定」のリンクが必要。

以上のような意見が述べられている。法制定は一応評 価はされるあのの，具体的にはあまり役にたたないので はないかということで，事実この法が発効してからス チール缶の値下りが起こり, 現在また古紙にもそれが及 んでいる。

この改正法をテコにして、これからの強い行政指導が 望まれる。

\section{4 廃棄物処理法について}

（1）相当強化されたと考える。従来の法は廃棄物の適 正処理を目的にしたものだったが，改正後は廃棄 物の排出抑制，分別再生等を目的に加え，関係者 の責務を明確に規定したことは評価できる。

多量の廃棄物を出す一廃排出者への減量計画の 作成等の指示規定は評価できる点であり活用した い。

○排出抑制，適正処理についての各々の責任が明 記されたことにより市町村では指導や協力が求 
めやすくなった。

(2) 運用面で従来弱かった点についてこの際強化を。 ○とりわけ一廃の事業者責任について自治体は あっと強く対応すべきだ。

○現状, 深刻な行き詰まりにある廃棄物行政に とって, この程度の改正では基本的な改善にな らない。

○市町村として具体策には苦慮している。 ○事業者の自己責任の範囲を判断しかねる。 ○企業よりでなく厳しい法律にすべきだ。 ○市の特殊事情や独自性が無視され，結果的には， 今まで以上に多くの処理困難物を市の責任で処 理しなければならなくなるのではないかと心配 だ。

○多量排出事業者に対するごみ減量計画などの作 成を指示できることになったのは評価できるが, 罰則規定がなく，実効性に乏しい。

○協力を拒否された時の処置が定められていない。

(3) 一廃と産廃の区分を明確にすべきだ。

。紙ごみなど事業系一般廃棄物や家屋新築時に発 生する木くず等が産廃になっていないなど区分 の見直しがない。

（4）市町村の努力だけでは限界。製造者の処理責任を 積極的に法整備してほしい。

（5）家庭から排出される処理困難物の製造者, 販売者 の処理責任を明確にすべきだ。

○特別管理廃棄物は処理困難物が多いので, 事業 者の責任で回収ルートの確立をしてほしい。

（6）自治体は事業者に適正処理を指示することができ るが，権限の裏づけがない。

○「事業者の責務は市町村への協力」の表現しか ない。引取を求める, 処理費用の一部負担を求 める等の具体的方法の明示がされていない。

(7) 20 条 2 のリサイクル事業者の登録はリサイクル 法でした方が効果がある。

（8）集団回収に対する国庫補助金の活用や自家処理に 対する適正な支援等についても検討願いたい。

（9）政令が公布されたばかりなので, 内容を十分理解 していない。 ○二法については検討中なので回答保留。
(10) 小規模処分場（特に安定型 $3000 \mathrm{~m}^{2}$ 以下）の設置 が法規制外では問題だ。

(11) 罰則規定の 16 条, 原状回復について, 要する費 用全額を罰則金とするなど厳しくすべきだ。

以上のような意見である。廃掃法は改正され，排出抑 制, 分別再生が目的に加えられ，関係者の責務を明確に したことは評価できるが，これを受けて自治体において 指導協力が求めやすくなったという反面この程度の改正 では基本的改善にならないと心配されている。

法律は作られたり, 改正されただけで実効をあらわす のではなく，これを如何に活用していくかにかかってい る。自治体はこれをもとにして, 自治権を十分発揮して ほしいし，それをしっかりと支えるのは住民の活動では ないか。みんなが力を合せて，今回の改正をしっかりと 受け止め, 十二分に活用したいものである。そのために あしっかりとした話合いの場が求められる。

\section{5 廃掃法改正後の対応}

条例を改正するという所が半数を占めている。その他 あかなり多く, 中であ検討中が非常に多い。改正した所, 改正予定なしという所むある。

市町村の処理計画の中に, 分別の区分を定めなければ ならないとあるがどのように変える予定かという問に対 する答は図 6 の通りで，その他の項あ検討中が多いが，

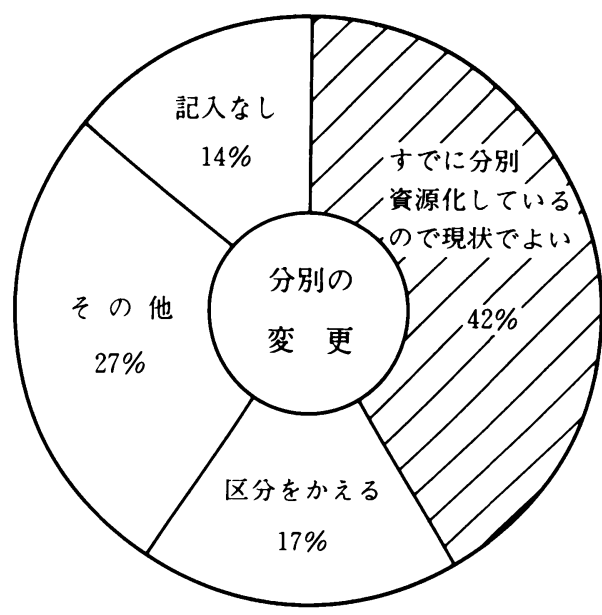

（図6）分別の変更

（表 3 ）すでに分別している所の分別数と区分をかえる所の分別数

\begin{tabular}{|c|c|c|c|c|c|c|c|c|c|c|}
\hline & 2 分別 & 3 分別 & 4 分別 & 5 分別 & 6 分別 & 7 分別 & 8 分別 & 13 分別 & 細分別 & 多分別 \\
\hline すでに( ) 分別している & 9 & 22 & 22 & 32 & 6 & 3 & 3 & 1 & & \\
\hline 区分をかえて ( ) 分別にする & 1 & 4 & 7 & 16 & 3 & 5 & 1 & & 1 & 1 \\
\hline
\end{tabular}


細分化を考えている所も何か所かある（表 3 ）。

多量排出の事業系一般廃衰物排出事業者に対する措置 について, 減量計画作成指示の予定は $36 \%$, 予定なし $28 \%$ ，その他 $25 \%$ ，記人なし $11 \%$ ，で北海道では指示 予定より予定なしが多く，東京では予定なしがない。

\section{6 有 料 化}

ごみ減量のきめ手として有効な方法に有料化がある。 現在有料化は $65.3 \%$, 予定が 8.1\%, 予定なしが $21.4 \%$, 記入なしが $5.2 \%$, 有料化もどの分が有料なのかは地域 によってもちがう。一般廃棄物 14\%, 事業系一廃 53\%, 粗大ごみ $17 \%$ ，その他 $17 \%$ ，となっている。半分以上 は事業系一廃でこれは当然といえば当然, 家庭系一廃と 事業系一廃は当然区別されるべきである。

では今後有料化を考えている所ではいつ頃実施予定か の問に,「 1 年末満」 $45.5 \%, 「 2 \sim 3$ 年」「3〜 5 年」 がともに 4.5\%,「未定」 $45.5 \%$ と回答。また，いつ頃か ら実施かとの問には昭和 30 年以前 $12 \%, 30 \sim 40$ 年 $4 \%, 40 \sim 50$ 年 $38 \%, 50 \sim 60$ 年 $18 \%, 60$ 年以降 $10 \%$ ，記入なし $18 \%$ 。

昭和 11 年頃から有料化されているが, 特に有料化が 多かったのが昭和 47 年で, 一般廃裹物, 事業系廃棄物, 粗大ごみともに進んでいる。20 年ぶりに「廃掃法」は 改正されたので, 前の改正時同様, 有料化が進むのでは ないかと推察される。有料化の中には，大量に臨時に出 た引越などの場合, $100 \mathrm{~kg}$ 以上なら $1 \mathrm{~kg}$ 当り 10 円と か 15 円とかをとるとか, 1 日平均 $10 \mathrm{~kg}$ 以上の特定の あのを有料としている所もある。その他の所にはそうい う例が沢山あげられていた。実施によって減量された市 あある。

\section{7 特別管理廃棄物 と処理困難物}

「特別管理一般廃棄物」「特別管理産業廃棄物」「廃棄 物処理困難物」に指定する必要があると思われるものを 上げてもらった。様々なものが上げられたが面白いこと に, 同じものが別の所に分類されているものあ多い。こ れらを一覧表にしてみた。毎日収集処理している人たち の答だけに是非この意見は尊重してほしい（表 4 ）。

\section{8 廃棄物隇量推進審議会と推進員}

第 1 章 5 条の 2 『市町村はその区域内における一般廃 棄物の減量等に関する事項を審議させるため, 廃棄物減 量等推進審議会を㯰くことができる』となっている。ま
た同様に推進員の規定もある。これらに対する対応につ いての回答が次の通りである（表 5 )。その他には名称 はちがうが性格の似た委員会を当てている。

\section{9 リサイクルセンター}

リサイクルセンターは設置が $22 \%$, 計画中 $22 \%$, 予 定なし 33\%。ほとんよ゙は 1 か所だが 2 か所以上も 5 市 あった。民間委託も何か所かあった。

\section{0 国，事業者，市民に対しての要望}

国に対して

（1）発生するごみの抑制を目的とした法体系の整備, 廃掃法の原則である「排出者責任の原則」を明確 に制度化すること，そのための社会経済システム をつくること (62)。

(2) リサイクル活動に関する助成や技術援助をするこ と, リサイクルセンターを増設し補助をふやす (61)。

（3）リサイクル法の強力推進, 対象業種の拡大, 業界 指導の徹底 (29)。

事業者に対して

（1）リサイクルを念頭においた企業活動，再生利用を 前提とした製品の開発および素材の利用, 容器種 類の削減 (73)。

（2）排出した成棄物については事業者は責任をもって 処理すべきだ（54）。

(3) リサイクル流通経路の確保, 回収システムの確立, 自社製品が廃棄物になった場合の回収ルートの確 保, 逆有償の現象が発生しないよう責任をもつこ と (52)。

市民に対して

（1）ごみ減量への協力, 分別の徹底などの協力, 可能 な部分を自己処理する（109）。

（2）市民一人ひとりの理解を自覚による生活のなかで の協力, 過剩包装を断わる, 使い捨て商品は買控 えるなどライフスタイルの変更, サービスセン ターなどを利用し補修につとめる。ごみは買わな いと強い意志をもつ。企業宣伝に負けるな（100）。 この他多数の意見があり, 現状打開のため重要なカギ でもあると思う。

熱心な回答をまとめつつ, 廃棄物処理ということの大 変さを改めて感じる。法律の改正を機に，みんなが意見 を出しあい一層協力をして進めなくてはならない。この 問題はもう一刻も待てないところにきている所も多く, 
（表 4）特別管理一般廃棄物, 産業廃棄物処理困難物に指定を望むもの

\begin{tabular}{|c|c|c|c|c|c|c|c|c|c|c|c|c|c|}
\hline 品 & - & & 産 & & $\begin{array}{l}\text { 処理 } \\
\text { 困覲 }\end{array}$ & & 品 & - & & 産 & & $\begin{array}{l}\text { 処理 } \\
\text { 困難 }\end{array}$ & \\
\hline 医 療 廃 棄 物 & & 30 & & 23 & & & 有害 廃 裹 物 & & 4 & & 11 & & 2 \\
\hline 感染性医療廃棄物 & & 29 & & 31 & & & 塗 料 & & 5 & & 1 & & 5 \\
\hline 家庭用医療廃棄物 & & 1 & & & & & 品 & & 4 & & 1 & & 3 \\
\hline 血液付着 ガーゼ & 63 & 3 & 57 & & 3 & & 油 & & 4 & & 11 & & 2 \\
\hline 注 射 針 & & & & 3 & & & フロン 含 有 & & 3 & & & & \\
\hline 医 療 器 具 & & & & & & 3 & 土壤 く ん 蒸 & & 1 & & 1 & & \\
\hline $\begin{array}{llll}ホ ゙ & \text { ヘ } & \text { 類 } \\
\end{array}$ & & 28 & & & & 18 & 農 薬 & & 2 & & 2 & & \\
\hline スプレー 缶 & & 14 & & & & 8 & 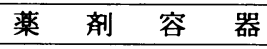 & & 1 & & 3 & & \\
\hline $\begin{array}{lllll}L & P & G & \text { ガ } & \text { ス } \\
\end{array}$ & 44 & 2 & 18 & 16 & 26 & & 農 器 具 & 32 & & 52 & 1 & 23 & 8 \\
\hline 小 型 ボ ン べ & & & & 2 & & & 廃 & & & & 4 & & \\
\hline 乾 $\quad$ 電 池 & & 18 & & 3 & & 10 & 廃 & & & & 4 & & \\
\hline 光 灯 & & 5 & & & & & 塩 素 系 廃 物 & & 1 & & & & \\
\hline $\begin{array}{lll}\text { 体 温 } & \text { 計 } \\
\end{array}$ & & 1 & & & & 2 & 腐 食 性 物 質 & & & & 2 & & \\
\hline 水 銀 & 28 & 2 & 8 & 4 & 12 & & 重 金 属 含 有 & & & & 5 & & \\
\hline 二カ & & 2 & & & & & 特 定 有 害 物 & & & & 2 & & \\
\hline ミ ウ ム & & & & 1 & & & 放 射 性 廃 物 & & & & & & 1 \\
\hline 電 & & 24 & & 3 & & 83 & $\begin{array}{lll}P & C & B\end{array}$ & & 7 & & 4 & & 2 \\
\hline テ $\quad レ$ & & 2 & & & & & 集 じ ん 灰 & & 14 & & & & \\
\hline $\begin{array}{llll} & ア & コ & \text { 冫 } \\
\end{array}$ & & 3 & & & & & 集 じ ん 器 & & 1 & & 1 & & \\
\hline 電 子 レ ン ジ & & 3 & & & & & $\begin{array}{lll}E & D & \text { 灰 }\end{array}$ & 17 & 1 & 1 & & & \\
\hline 石油ストーブ & & 1 & & & & & ば い じ ん & & 1 & & & & \\
\hline パ ソ コ & & 2 & & & & & 消 火 & & 5 & & 2 & & 14 \\
\hline ホームテレフォン & & 1 & & & 156 & & $\begin{array}{llll}\text { 紙 お方 } & \text { む }\end{array}$ & & 1 & & & & 4 \\
\hline 電気カーペット & 42 & & 4 & & 156 & 2 & コンクリート & & 1 & & & & 2 \\
\hline 充 電 式 家 電 & & 1 & & & & & 貝 類 & & 1 & & & & \\
\hline 家 具 & & 1 & & & & 7 & 再 生 不 能 品 & & & & 1 & & \\
\hline スプリングベッド & & 4 & & 1 & & 54 & 防腐剤含有木材 & & & & 4 & & 2 \\
\hline スチール家具 & & & & & & 1 & 飛散アスベスト & & & & 13 & & 1 \\
\hline ピ $\quad 3 \quad$, & & & & & & 3 & 空 缶, 空 ビ ン & & & & 2 & & \\
\hline 粗 大 ご み & & & & & & 6 & 動 物 性 残 渣 & & & & 1 & & \\
\hline 火 薬 花 火 & & 5 & & 1 & & & 残 土 & 8 & & 24 & 1 & 38 & 1 \\
\hline 灯油ガソリン & & 2 & 7 & & & & パチンコ 台 & & & & & & 1 \\
\hline $\begin{array}{lll}\text { 爆 } & \text { 発 } & \text { 物 } \\
\end{array}$ & & & 7 & 5 & & & コンプレッサー & & & & & & 1 \\
\hline 火 & & & & 1 & & & 浄 化 漕 & & & & & & 2 \\
\hline 自 & & 1 & & 1 & & 22 & ピルピット污染 & & & & & & 1 \\
\hline バ & & 6 & & 1 & & 36 & 下 水 道 污 泥 & & & & & & 1 \\
\hline 夕 $\quad 1 \quad$ 促 & 17 & 6 & 6 & 2 & 1 & 70 & 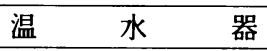 & & & & & & 1 \\
\hline バ ッ テ リ & 17 & 4 & 6 & 1 & 147 & 13 & $\begin{array}{llll}7 & 1 & \uparrow & -\end{array}$ & & & & & & 1 \\
\hline 自 動 車 新 品 & & & & & & 3 & 破裂性 ガラ ス & & & & & & 6 \\
\hline 自 転 車 & & & & 1 & & 3 & 検 討 中 & & 3 & & 3 & & 5 \\
\hline 廃 プラスチック & & 2 & & 1 & & 7 & 政 令 で 指 & & 3 & & & & \\
\hline プラトレー & & 3 & & & & 2 & 未 & & 2 & & 1 & 6 & 1 \\
\hline ペットボトル & & 1 & & & & 3 & 後 検 & 9 & 1 & 6 & & 6 & \\
\hline $\begin{array}{lll}\mathrm{F} & \mathrm{R} & \mathrm{P} \\
\end{array}$ & 6 & & 2 & 1 & 22 & 4 & $?$ & & & & 1 & & \\
\hline 灯 油 夕 ンク & & & & & & 1 & 法できめられた物 & & & & 1 & & \\
\hline 農業用ビニル & & & & & & 3 & 未 指 定 & & & & & 1 & 1 \\
\hline $\begin{array}{ll}\text { 浴 } & \text { 漕 } \\
\end{array}$ & & & & & & 2 & & & & & & & \\
\hline
\end{tabular}


（表 5 ）廃裹物减量推進審議会, 推進員について

\begin{tabular}{|c|c|c|c|c|c|c|c|c|c|c|c|}
\hline & \multicolumn{6}{|c|}{ 廃棄物 減量推進 審議会 } & \multicolumn{5}{|c|}{ 廃裹物減量推進員 } \\
\hline & 総 数 & 設 置 & 計 画 & 検討中 & その他 & 記入なし & 置 & 計 画 & 検討中 & その他 & 記入なし \\
\hline 北海道 & 17 & & 1 & 12 & 2 & 2 & 1 & 1 & 10 & 2 & 3 \\
\hline 東 北 & 31 & 5 & 1 & 20 & 2 & 3 & 3 & 2 & 21 & 2 & 3 \\
\hline 関 東 & 67 & 9 & 8 & 31 & 12 & 7 & 4 & 4 & 40 & 7 & 12 \\
\hline 東 京 & 16 & 5 & 1 & 8 & 1 & 1 & 1 & & 12 & 1 & 2 \\
\hline 中 部 & 34 & 6 & 5 & 14 & 6 & 3 & 4 & 5 & 16 & 4 & 5 \\
\hline 近 畿 & 54 & 9 & 4 & 33 & 4 & 4 & 3 & 5 & 36 & 4 & 6 \\
\hline 中 国 & 18 & 3 & 1 & 11 & 2 & 2 & & 1 & 12 & 3 & 2 \\
\hline 四 国 & 10 & 3 & & 5 & & & 1 & & 7 & 1 & 1 \\
\hline 九 州 & 24 & 1 & & 18 & 3 & 3 & 3 & & 17 & 1 & 3 \\
\hline 合 計 & 271 & 41 & 21 & 152 & 32 & 25 & 20 & 18 & 171 & 25 & 37 \\
\hline $\mathrm{N}=271$ & $100 \%$ & $15 \%$ & $7 \%$ & $56 \%$ & $13 \%$ & $9 \%$ & $7 \%$ & $7 \%$ & $63 \%$ & $3 \%$ & $14 \%$ \\
\hline
\end{tabular}

今はまだ少々余猶のある所む近い将来同じ状況がやって くることは間違いのない事実だと思われる。

地球環境を守り, 廃率物処理をスムーズに進めるため
にはみんなの努力が必要である。リサイクルが進むため にも，国む企業も市民も，これからも努力しなければな らない。 